\title{
(A) )
}

\section{I am what I am: Exploring the identity construal in Pakistani School EFL Textbooks}

\section{${ }^{a}$ Tazanfal Tehseem, ${ }^{b}$ Naima Tassadiq, ${ }^{c}$ Rabia Faiz, ${ }^{d}$ Lala Rukh}

${ }^{a}$ Assistant Professor at the Department of English, University of Sargodha, Pakistan

Email: tazanfal.tehseem@uos.edu.pk

${ }^{\mathrm{b}}$ Research Scholar at the Department of English, University of Sargodha, Pakistan

Email: naimatassadiq01@gmail.com

${ }^{\mathrm{c}}$ Assistant Professor at the Department of English, University of Sargodha, Pakistan

Email: rabia.faiz@uos.edu.pk

${ }^{\mathrm{d}}$ Research Scholar at the Department of English, University of Sargodha, Pakistan

Email: lalarukhmalik7@gmail.com

\begin{tabular}{l}
\hline ARTICLE DETAILS \\
\hline History: \\
Accepted o5 Ahugust 2021 \\
Available Online September 2021
\end{tabular}

Keywords:

Genre Analysis, Textbooks, Identities, Systemic Functional Linguistic

\section{JEL Classification:} I21,

DOI: $10.47067 /$ ramss.v4i3.174

\begin{abstract}
This paper aims at exploring how identity is construed in children's literature and how the powerful legitimize to identify the textbook consumers by exercising their influence. Drawing on Systemic-functional Linguistics (Halliday and Matthiessen, 2014), particularly Genre theory (Martin and Rose, 2008), it examines how English language textbooks used in Pakistan are written to construe, a project, and normalize a particular sociocultural identity. The sociocultural positioning being projected through the textbooks can be norm-conforming, contesting or can suggest otherwise. The majority of the students in Pakistan are mandated to learn state governed textbooks which serve them build up a sociopolitical identity. Therefore, underlying semiotic modalities realizing a perspective are pertinent to be explored in order to unfold discursive strategies for constructing identity. It is widely acknowledged that any educational curriculum is the most effective tool to construct and circulate a reality. Therefore, challenging any literacy pedagogy embedding particular outcomes can help transforming educational practices across the school curriculum (Martin and Rose, 2012). The data comprises Punjab English textbooks for the government schools. The findings suggest that the intriguing intricacies of textbook discourses can be successfully examined through analyzing linguistic patterns and that the textbooks construe sociocultural identity. The findings also provide insightful implications for discourse analysis based on SFL by contributing explorations of identity.
\end{abstract}

(C) 2021 The authors. Published by SPCRD Global Publishing. This is an open-access article under the Creative Commons Attribution-

NonCommercial 4.0 


\section{Introduction}

Bucholtz and Hall (2005) state that "identity is the positioning of self and other" (p. 586). As compared to the past, the identity is no more a fixed criterion. Benwell and Stokoe (2006) postulated that identity in the first glimpse is a projection of one's self and is further developed into the perception of a social and collective identity (p. 17). From this notion, the identity became a subjective enterprise. Identity is constructed and negotiated via discourse which incarnates in itself the social semiotics (Bucholtz \& Hall, 2005, p. 586). Martin \& Rose (1991) conjugated social semiotics with the genre by relating that genre is a socially distilled type of text that contains grammar, lexis, dialogism, narratives, and discourse which are consummated as a semiotic resource of interaction. This paper is an attempt to enlist this approach drawing particularly on Systemic Functional Linguistics through genre theory. It scrutinizes the English textbooks employed in Pakistani schools, which are used as, a written medium to shape and predict the identity of a student. This paper operationalizes SFL as a medium to recognize the ideational and textual metafunctions that enable a student to develop an identity and its view of the world.

This paper further parses the English textbooks written and used in the Pakistani context, Punjab. The charisma of Indexicality factor visibly present in textbooks relates to the semiotics of linguistic forms to identify a person to a social construct (Bucholtz \& Hall, 2005, p. 596) and through this identity became a style when it comes to semiotics. Behind the veil of identity, ideology plays the role of paramount constituent. Ideology is a construct of hegemony, which are prevailed through educational manifestations. To probe out the prevalent relationship among identity and ideology incarnated in the curriculum through education, two frameworks have been implemented firstly, the content of the textbooks are seen under the lens of Genre theory and secondly, through SFL, the ideational and textual metafunctions are being explored.

Wang (2016), in establishing a relationship between schools and ideologies, stipulates that through textbooks schools impart ideologies among the students. It contains social, cultural, political, economic, religious, and all other dimensions that help in making the identity of a person, withal, Apple (2019), envisions that education constructs our identity at two levels; first at the individual level and secondly, at the broader level (national or international). Ideology and curriculum are interlinked as it shapes up an institution, the knowledge being formed, and the instructor. Consequently, Apple 1978 links out that educational institutes have domineering power in society. Schools are important to maintain the social order. They are considered a source of 'legitimate knowledge'. Schools serve to promote the ideologies of the powerful ones (p.63).

The findings illustrate that textbook promote three foremost identities by exerting the genre theory and SFL. Hence, in considering the findings discern that how educational institutes fabricate our identity and make us social animals by narrowing down our vision and individual will.

Moreover, this study pinnacles out that how identity is constructed through Punjab Government textbooks in Pakistani schools. Mahboob (2015) relates that Pakistani textbook denote the religious and political identities constructed among the students. Through this, they develop a norm to be followed by all social members. This paper focuses on textbooks which are only the essence of educational institutes. Since the majority of the population attends the schools only so the basic hidden identities found their roots to be implanted in the minds. 
Mehboob (2013) points out the identity management and language variation in his article. He focuses on the government-approved textbooks being taught in Sindh. He examined the content and the language used in the textbooks promote hidden ideology and how it makes the identities. He says that through these textbooks we can make our local identity that is acceptable to a particular socioeconomic forum. He highlights that the educational system does not serve for education anymore rather it has now become a zone of experiments done by the powerful groups which unknowingly is affecting the construction of prevailing identities.

This study aims to determine that how Government schools in Pakistan can utilize instructive materials to develop their identity to keep up with the socio-economic status. The status assumes a part in controlling the substance and language introduced in the educational plan. To highlight the ideological paradigm of textbooks that are part of children's educational habits and try to manage their identities.

\section{Review of Related Literature}

Ideology and identity are invariably a matter of thrust for scholars and an enormous altercation has been done over it. Bucholtz \& Hall (2004) elucidates that identity and ideology are interconnected by power representing beliefs and ideas given culturally. Ideologies can easily manipulate the social, political, economic, and religious aspects of a person. It helps people to maintain a position in a social world. Verschueren (2012), indicates that ideology and identity are linked together. Ideology prevails among all genres that are education, teaching, reports, and other mediums. It creates a hegemony by the dominance of the powerful people. Identity is one of the major themes of ideology. Ideology forms the reality and a norm that is acceptable in a social world (pp. 10-12). Shahrebabaki (2018) relates that identity means sameness, an association with a particular social group. One can identify themselves with the linguistic variety used (pp. 217-220). Fina et al. (2006) demonstrate identity is rooted in history, not as a conscious process. Furthermore, Fina (2018) pins out that there are many types of identities such as individual, collective, social, personal, and situational. Though both of them are interconnected and are shaping each other (pp. 268-269). Milner (2010); Bucholtz \& Hall (2005); Kopytowska (2012); Bernstein (1998); and Kress \& Hodge (1993); to cite a few, stipulates that identity is not constant, it is always in action, is inculcated in representation, and enactment, and there is always an actor and a viewer.

Textbooks and curriculum are the centre of any educational medium to nurture the hidden motives of any powerful group. Nuan et al. (1998) state that curriculum refers to expectations related to what is to be learned, its purpose, its outcomes, evaluation, and the role of teachers. Moreover, Branzila (2018) postulates that children's literature acts as a medium to connect its readers to a social acting world by fantasizing about it. It instils personal, national, and traditional identity besides textbooks. It also promotes national identity in them. Barnard (2004) states that textbooks serve ideological purposes as they came directly out of society. Students came immune to ideologies and consider it as a fact that data presented in the textbooks are considered factual and authentic, which makes up a society. Curdt-Christiansen \& Weninger (2015) highlights that textbook make ideologies visible representing the social structure of society. Textbooks contain historical, cultural, social, and economic outlooks. Content presented in textbooks is official that has a determination behind it. It contains both visible and underpinned aspects that lie in the construction, counts, and impacts of knowledge. Shah et al. (2013), further constitutes that textbook used in schools are of political and educational interest. Textbooks are seen in a conflict between them. Punjab matric level textbooks promote religious ideology. This textbook has negated the freedom to 
act, of speech, and promote mostly religious ideology. It is done to promote the ideology of political beliefs (pp. 113-120).

Since each discourse is a quintessence of a subsequent genre similarly, there are a couple of genres being adopted by curriculum creators. In this sense, Swales (1990) proposed that Genre is the distribution of texts in different categories. It helps to know about the language used in a setting. It has its role in academic discourses also. One can differentiate among genres through the discourse incorporated in a text (pp. 01-28). A genre can be of any type such as literary studies, written, videos, rhetoric, spoken, music, folklore, and linguistics. It's all about choice as its hidden motive is to highlight the socially accepted norms and values (pp. 33-34). Bawarshi (2000) states that the genre functions as a social venture as it helps us to execute their selves in a social world. It helps in realizing the situation and the roles we have to perform that is to function up the identity. Through different genres, one can perform differently and multiple identities merge out of it. By reading different genres we can easily perform in a social semiotic world.

\section{Methodology}

This paper scrutinizes identity erection via textbooks, in Pakistan, by application of Halliday's model of 'Systemic Functional Linguistics' specifically on ideational and textual metafunction. The research sample was extracted from the approbated Pakistani English textbooks of grades 7, 8, 9, and 10 and total texts are twenty-one (21) in number employed by Government schools of Punjab. The basic paradigm of this study was to analyze the textbooks at two general levels. The first level was to analyze the content of the book. Secondly, by anatomizing the language used, in the books by implicature of Halliday's 'Systemic Functional Linguistics' model of ideational, and textual functions.

In the light of Halliday's 'Systemic Functional Linguistics' the present study aims at exploring the answers of the questions, mentioned below:

1. How identities are imprinted on the mind through textbooks?

2. What are the genres used in textbooks to establish identities?

3. What are ideologies behind the identity construction implied through textbooks as a tool?

\section{Theoretical Background}

Halliday introduced three metafunctions of language termed as an interpersonal, ideational, and functional stratum. These are the potential functions performed by a language in terms of social interaction and ideology construction. These metafunctions lay bare the lamina of how a language is used in a context and how it is realized. Language is used as a system as realized in a textual mainframe.

The Ideational function is the construction of social actions performed by a person. It is involved in construction, recursion, and retain any experience. It is related to the semantic and functional manifestations of language rather than syntactic orientation. The main concern of ideational function is: the illustration of content and conveying of information. It helps in constructing shared competence amongst a discrete community. A text can be varied as general, specific, structured, and unstructured. To explain how an action is performed and the processes involved in it. The textual function is related to the verbal world, particularly, how the information is presented in a text. It is all about part and parcels of a sentence as an encoded message. It is the illustration of competence (identity in general) utilizing verbal expression incarnated in a textual 
form. It involves the portrayal of self by the language incorporation in a piece of text. It is concerned with the realization of a text as a dialogue or monologue, either the field is accompanying or constituting. Although there is no thorough designation of the context of culture, yet some of the comprehensive classes of context have been acknowledged for quite a while, and they are manifested in three subsequent terms: field, tenor, and mode.

Genre lies beyond the boundaries of language given by Halliday. It accompanies all aspects of a text in a single term. It gives power to people to control and manage the ideology they tend to promote. Genre is a wider term containing interpersonal, ideational, and textual metafunctions in it. The genre can be divided into histories, reports and explanations, and stories. The historical genre focuses on past events and shows the manipulation of time. They aim to promote that what causes leads a particular event and their long-established effects. Under the historical genre typology came biography (focuses on life accounts), history (centers at the public chronicles), and personal recounts (its pivot is personal narrative). In reports and explanations, the data is classified, described, observations, experiments, and the effects of viable causes. The categories that came under this genre are factorial (constitute the facts and figures), sequential means (manifest the cause-and-effect relationship), and consequential effect (how multiple causes affect a single event). In a story, we have the fables and stories having some orientation, complication, and resolution. Their impetus is to educate students by narrating the accounts of the others and to infer a lesson from it. The last genre is poetry that has a rhythm and has a musical quality to have an enduring effect on every soul.

\section{Discussion and Analysis}

Identity management is done in the textbooks approved by the government in various ways. One can identify it through the language and ideologies promoted in a text that is the content of the English textbooks. Another way is to analyze it through the language in the textbooks. The analysis is done at both content and language levels.

\subsection{Content analysis of the Textbooks}

Textbooks provide us with a wide range of the contents accompanying all aspects of life. The choice of content placement is done at a higher level as it points out the hidden ideologies. We have followed Martin \& Rose (1991) expresses that "genre as part of a functional model of language and attendant modalities of communication." The government only approved those contents that are in favor of their ideologies and curriculum is spread in the district as a national curriculum and implicitly ideologies are promoted. Through content analysis, we can analyze the distribution of the material in disparate genres. By analysing the contents of Punjab government-approved textbooks of grade $7,8,9$, and $10^{\text {th }}$ class we came to know that identities are promoted by placing the materials of different genres in a single textbook. By analysis, we ascertain three identities religious, national, and moral.

\subsection{Genre Analysis}

Genre distribution of the texts present in the textbooks are done to know about the recounts and the placement of the narratives. The Genre accompanies every aspect of life either verbal, nonverbal, chats, etc. In a social context, the genre can be seen as a functional model. Their purpose is to promote the implicit and explicit motivation and the effect produce by it. It shows that what writers have written and the reasons behind it. We can analyze the content, style, structure, language, and audiences. The contents of English textbooks of grades 7, 8, 9, and 10 are divided into four genres historical, reports and explanations, the story, and poetry. 
Within the medium of the historical genre, text can be divided into a biographical, historical, and personal recount. Texts such as "The Last Sermon of Rasool Hazrat Muhammad "Tolerance of the Rasool "Sultan Ahmad Masjid”, "Hazrat Muhammad an Embodiment of Justice" contains histories. "Quaid-i-Azam”, "Hazrat Umar (R.A)”, "Hazrat Asma (R.A)”, “The Quaid's Vision and Pakistan" illustrate biographical recount. "Eid-ul-Azha", "Faithfulness" lies under personal narrative. "The Saviour of Mankind" comes under the category of narrative (history). "All is Not Lost" comes under the category of a personal recount. "The Rooster and the Fox", "Clever Mirchu”, "A Great Virtue", "Try Again" demonstrate the genre of the story as moral lessons can be taught more effectively through the form of stories as compared to facts. In reports and explanation genre, the "Traffic Sense" describes the consequential effect. "Hockey" contains factional information and the importance of the sport. "Patriotism" lies under the sequential explanation. “A Nation's Strength”, "Prayer” accompanies the genre of poetry. Where a Nation's strength is related to national identity and Prayer plays its role in the construction of religious identity.

\subsection{Language of the Textbook}

Identities are constructed in Punjab government-approved English textbooks through the use of language. In a written text, the incorporation of language is vital. Language plays an intrinsic role in the maintenance and sustenance of identity. It enables people to know their culture and to be known in a social world.

\subsection{Religious Identity}

Werbner (2010) points out that the construction of religious identity is done at a broader level. Power plays a vital role in its maintenance. It makes people inclined towards religion, ritual, and its performance in a social world (pp. 240-244). Language pertaining to religious words, rituals, and religious personalities are integrated into English textbooks. Biographies, histories, personal recounts, and poems play a requisite role in promoting religious identities.

\section{Text 01: The Last Sermon Of the Rasool Hazrat Muhammad (Pg. 01, book 7, Punjab Curriculum \& Textbook Board, Lahore)}

This text promotes religious identity by representing one of the incidents from the life history of Hazrat Muhammad the last prophet. The text starts with the description of religion Islam and followed with the last preaching of Hazrat Muhammad on the occasion of Hajj, on " 9 " Zil-Hijjah" at Arafat, an Islamic liturgy. It lies under the historical genre, in which He promotes Islam and the comprehension of the substantial spirit of the religion. The main points of the sermon were that the only praiseworthy is Allah, equality of people, all are the lineage of Adam, accountability, rights of women, inheritance, the issue of debt, the punishment of criminals who committed has to face it, and the Book of Allah as guidance for all. These words are highlighted and at the end, everyone witnessed the message of the religion and its codes and conducts are being conveyed thoroughly by Rasool . In the end repeated this sentence "O Lord: Bear Thou witness unto it" two times to ensure that He has completed the task given by Almighty Allah.

\section{Text o2: Eid-ul-Azha (Pg. 28, book 7, Punjab Curriculum \& Textbook Board, Lahore)}

By placing an account of a religious festival of the Muslims that is "Eid-ul-Azha", commemorated on " $10^{\text {th }}$ of Zil-Hajjah", the component of sacrifice is being established, a salient religious strand. The description of the chapter states the motif of that festival is to promote brotherhood. The words employed here are festival, celebration, brotherhood, rejoice, devotion, 
affirmative, bade, memory, sacrifice, religious, enthusiasm, millions, and butcher are written in bold words to show the significance of this festival, a religious practice to be accepted by all. This chapter highlights that the share we have should be divided into three parts equally, to realize the desolation and necessitates of the needy ones and the neighbors and focus on poor relatives.

\section{Text 03: “Tolerance of the Rasool (Pg. 01, book 8, Punjab Curriculum \& Textbook Board, Lahore)}

This text shows religious identity by foregrounding the proceedings from the life of Rasool

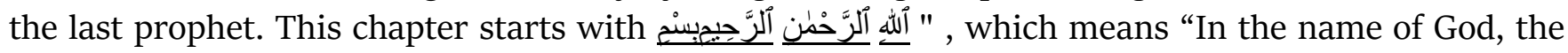
Most Gracious, the Most Merciful". The text then follows the accounts of tolerance from the life of Rasool. Words such as revenge, conquest, amnesty, destroy, recognize, troubled, custom, forbidden, objected denotes that whatever bad circumstances may occur one should remain tolerant as our Rasool was. The account of Taif incident has been given that despite all of the inequity He promoted peace and brotherhood and has forbidden revenge and fostered tolerance.

\section{Text 04: Prayer ((Pg. 55, book 8, Punjab Curriculum \& Textbook Board, Lahore)}

The text "Prayer," lies under the genre of poetry, starts with an image of a girl fully covered from head to toe, sitting on the mat, her hands are lifted up, and making a prayer. Language use in the poem embodies the significance of prayer and why everyone should offer it. As the last three lines "Not to remind You, Of me, But myself, Of this and all of You" depict the hidden ideology that prayer is important for all to be practiced but done through an individual instance. The religious motif is not imposed directly but through a lesson-like quality.

\section{Text 05: Hazrat Umar (R.A) (Pg. 6o, book 8, Punjab Curriculum \& Textbook Board, Lahore)}

Through the biography of "Hazrat Umar (R.A)", one of the Caliphs of Islam, through a powerful religious figure, religious identity is developed. By explaining the accounts of the life of Hazrat Umar (R.A), it is shown that how he embraced Islam, his Caliph period, his attitude towards his people, his attitude with servants, and he died while offering Namaz. The last account predicts that one should not be worried about the death being on religion Islam and he was killed while offering Namaz promoting a vigorous religious message.

\section{Text o6: The Saviour of Mankind (Pg. o1, book 9, Punjab Curriculum \& Textbook Board, Lahore}

In the text "The Saviour of Mankind", the language employed shows that how a non-civilized community is being transformed into a civilized one. There is an embodiment of Quranic verses such as from (surah 96 aayat 1-5) and (surah 33 aayat 45-46) that represent the divine message in the following chapter. The following text portrays the process of dive message revelation and Rasool missions promote the message of Allah and the message of Tauheed. Islam has been seen as a religion of civilization and shows the right way of living and the hurdles faced by Rasool in the spread of Allah's message. And the statement of Hazrat Ayesha (R.A) at the end of the text summarises the whole text that 'Hazrat Muhammad was an embodiment of Quran'.

\section{Text 07: Hazrat Asma (R.A) (Pg. 32, book 9, Punjab Curriculum \& Textbook Board, Lahore)}

The biography of "Hazrat Asma (R.A)" is present, though not a clear biographical genre but shown from a religious perspective. There is an embodiment of the Arabic language, in the third paragraph, some services of her are depicted. But, the remaining chapter is related to her closed ones and their services towards Rasool She (R.A) is being represented as the one that had a pearl of 
great wisdom and knows how to protect her loved ones and relatives. She is an embodiment of courage and generosity and no matter in what circumstances you are have firm faith in Almighty Allah.

\section{Text 08: Sultan Ahmad Masjid (Pg. 73, book 9, Punjab Curriculum \& Textbook Board, Lahore)}

In the text, "Sultan Ahmad Masjid", there is the picture of the Mosque, for Muslims a respected place and is related to the house of Allah. The chapter highlights the importance of Sultan Ahmad Masjid, its construction, the addition of Ayat (verses) from the Holy Quran, and the importance of Namaz. It was constructed betwixt 1609 to 1616 , knowing worldwide as the Blue Mosque, made in the reign of Ahmad I. This text pinnacles out that Islamic architecture is splendour and has a wide history and Masjid plays a vital role in Islam.

\section{Text 09: "Hazrat Muhammad an Embodiment of Justice" (Pg. o1, book 10, Punjab Curriculum \& Textbook Board, Lahore)}

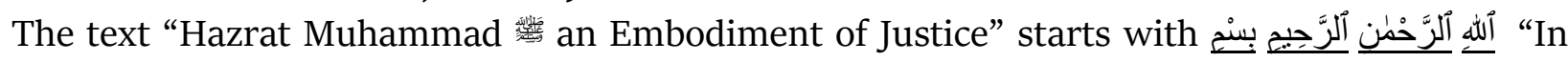
the Name of Allah, the Most Gracious the Most Merciful". It embodies religion and its imposition. There is the use of Arabic language as in and the sayings of the Prophet It was more a moral lesson promoting religion. When a person wants guidance, success, goodness, morality, piety, spirituality, and in any field of life they can look up at one person that is Hazrat Muhammad. This text points out His ways of resolving the issue by narrating the incident of Black Stone, His way of doing justice explained by a Qureshi woman incident and the trust $\mathrm{He}$ has from the nonMuslims by accounting the experience with His enemies, Jews.

From the above analysis, we came to know that there is a hidden ideology in the selection of a curriculum. Religious texts include pictures, language, religious personalities to make people aware of them. Through this, religious identity is developed as there is an on and off coalesce of religion in textbooks. Unconsciously we are made aware of it and when we go into a social world, we employ those implicit identities.

\subsection{National Identity}

Popow (2014), pinnacles that the nation is one of the constituents of a person's identity. Patriotism is endorsed among people at a local level, global level, through mass communication, and through social media platforms. It is done at the micro as well as macro level. And in all this scenario the pivot is language and the use of language and how influential it is and what impression it left a mark upon people. Nations are constructed, through this our relations are constructed, we became social animals and ultimately lead to identity formation (pp. 03-05). National identities in English textbooks of Grade $7,8,9$, and $10^{\text {th }}$ are constructed through respected genres such as factional, explanation, biography, and poem.

\section{Text 10: A Nation's Strength (Pg. 89, book 7, Punjab Curriculum \& Textbook Board, Lahore)}

The national identity is promoted through the poem "A Nation's Strength". This poem highlights the importance of a nation and how to take hold of it. People, honor, stand fast, suffer, brave, dare, pillars are written in bold form to convey the hidden ideology. The poem's ideology is to make people conscious of what the nation demands from them and what role they have to perform. Word choices imprint an enduring effect within the minds of the people that only those who are brave and work hard can do this. This nation does not approve any idle man but the one that acts as one of its strong pillars. 


\section{Text 11: Quaid-i-Azam (Pg. 113, book 7, Punjab Curriculum \& Textbook Board, Lahore)}

This text contains the biography of our leader, the national hero Quaid-i-Azam. His determination, his conscientiousness, and his role in making Pakistan, a separate homeland for Muslims. The first paragraph contains his early information that he was born in 1876, from where he gets early and higher education. In 1905, he joined politics and started doing efforts for the unity of Hindus and Muslims. But in 1930, he was convinced that Hindus and Muslims can't be united and implemented Iqbal's vision of a separate land. Because of his efforts and ascertainment, Pakistan came into being in 1947. Though he has to face many problems but his motto was "Work, Work, and Work" and he died in 1948.

\section{Text 12: Hockey (Pg. 46, book 8, Punjab Curriculum \& Textbook Board, Lahore)}

"Hockey" is our national sport and through this, the national spirit is revived. Firstly, the importance of sport in ones' life is depicted and the words such as fundamental, contribute, and adherence are used to make an impact. Then in the second paragraph, there is a worldwide depiction of sports and hockey among one of them. The third paragraph highlights Pakistan's victory in the sport. In the fourth and fifth paragraphs, there is the depiction of the number of players in the sport and how a match proceeds. Firstly, only men take part in that sport now, women also take part in that sport. And in the last paragraph, the achievements that Pakistan has. The language used and the presence of factional data is to make people motivated and take more part in making the nation proud.

\section{Text 13: Patriotism (Pg. 12, book 9, Punjab Curriculum \& Textbook Board, Lahore)}

The text "Patriotism" builds a national identity indicated from the title that shows devotion towards a country. The following text deals with what is patriotism, what role this feeling performs in a person's life, the role of Quaid-i-Azam, the true spirit of patriotism, and at the end a quotation to develop patriotism among people. The text starts with the definition of patriotism means devotion to motherland and being able to do any sacrifice for the country. The role of Quaid-i-Azam in making a separate homeland for the subcontinent Muslims and promoted that 'patriotism makes a nation strong and united.' And it further explores the role of the militiary in making a strong nation and the importance of native land where one can breathe freely and easily.

\section{Text 14: The Quaid's Vision and Pakistan (Pg. 62, book 9, Punjab Curriculum \& Textbook Board, Lahore)}

The present text is allocated to the biography of the founder and leader of Pakistan Quaid-iAzam that is "The Quaid's Vision and Pakistan". The respective chapter contains the picture of Quaid-i-Azam which makes us proud and enthusiastic to read more about it. The chapter starts with the depiction of Quaid-i-Azam as a savior to take people out of a difficult time. His statement is endorsed to make people motivated to have a separate nation, don't fear death when it comes to your nation. He focuses on a nation and its building and how we stand as different ones'. The ideology behind a nation and Quaid's role in making Pakistan. This text focuses on Quaid's tour of countrywide and he endorsed the concept of oneness among the nation that is 'we are different in terms of culture, civilization, language and literature..., a distinctive outlook of life.' His ideology behind Pakistan and a question to ponder out that we are truly endorsing the Quaid's vision or it is lost? 
Curriculum selection in textbooks promotes the ideology to promote a national spirit among people. To make people conscious of the nation, what it needs, and if it demands sacrifice be in the front line and promote national identities among students.

\subsection{Moral Identity}

Hart (2005), indicates that the purpose of moral identity is self-assessment. It is to know our moral failures, actions underline morality, and the awareness of psychological motifs of morality. Its purpose is to do the process of self-evaluation and through the faults and follies of others, we can transform ourselves (pp. 165-175). In grade 7, 8, 9, and $10^{\text {th }}$ textbooks moral identity is formulated through stories (fables), and a personal account.

\section{Text 15: Traffic Sense (Pg. 53, book 7, Punjab Curriculum \& Textbook Board, Lahore)}

"Traffic Sense", promotes a moral sense of our duty to follow rules and regulations to avoid unfavourable circumstance. In the text, words such as accidents, carelessness, a vehicle, aware, approaching, traffic sense, a moment, risk, minimize, the zebra crossing, signal, queue, levelcrossing, railway track, and violation of consciousness of people about the dangers. The language employed first threatens people of not following the traffic rules and then rules are given to avoid accidents. This chapter also questions that being a responsible citizen you observe the rules or not and road signs are understandable.

\section{Text 16: The Rooster and the Fox (Pg. 126, book 7, Punjab Curriculum \& Textbook Board, Lahore)}

In "The Rooster and the Fox", through fable, the hidden ideology promoted here is morality among people. The language employed shows a narration and by the adverse behavior of fox and ethics of a rooster, morality is being imparted. Words such as cunning, and tricks are being used for fox and rooster innocent yet clever. Through fox, cunningness is shown that one who makes a dig for others may himself falls into it. One cannot have the desired outcomes if they outlined the moral boundaries.

\section{Text 17: Clever Mirchu (Pg. 38, book 8, Punjab Curriculum \& Textbook Board, Lahore)}

In "Clever Mirchu" it is depicted that how one person with quick instincts in a difficult situation can save other people's lives. The story highlights the concept of togetherness and family bond. Mirchu is the youngest son of a farmer and is called Mirchu because his size was like pepper. The text highlights that accomplishments, the role performed, ability to face problems are not dependent on the size rather one's ability to think effectively in unsatisfactory events.

\section{Text 18: A Great Virtue (Pg. 65, book 8, Punjab Curriculum \& Textbook Board, Lahore)}

"A Great Virtue", serves a moral purpose that no matter how a poor person is, it is the virtuous intentions that matter. Words used here are terrible, followed, hesitation, step in, manage, shelter, accommodate, generous, shivering, and guilty. One should try to help others when he/she has a small amount of it as done by the old man who hut was that small that people stand in that to avoid the storm. The story pinnacles out the theme that when a person does good with others ultimately good also falls in its destiny.

\section{Text 19: All is Not Lost (Pg. 93, book 9, Punjab Curriculum \& Textbook Board, Lahore)}

It contains a personal recount that is "All is Not Lost", which manifests the personal experience of a nurse. It is to know how a little help can save a life and bring families hope. She as a 
nurse does not lose hope over a patient and little hope in unfavorable circumstances is like a light in a dark room. This text highlights the problems a nurse has to face in the profession and being composed in tough situations is the utmost demand of this profession.

\section{Text 20: Faithfulness (Pg. 149, book 10, Punjab Curriculum \& Textbook Board, Lahore)}

It contains a personal account, "Faithfulness", to which the title represents a moral purpose. This chapter accounts for an incident of Caliph Hazrat Umar (R.A), and a villager. The Caliph's task was to find out a murderer and should not punish an innocent person. After three days the true accuser is being found out and punished. In the end, the faithful act is performed as they forgive the murderers and gave the moral purpose that to forgive someone is a divine act. If you have faith in Allah then nothing is impossible.

\section{Text 21: Try Again (Pg. 27, book 10, Punjab Curriculum \& Textbook Board, Lahore)}

The poem "Try Again”, highlights a moral lesson of not giving up hope and to being contended. Success is not achieved at the first go rather one has to face failures to be successful. One should not feel disgrace in striving for success rather one should try again and again.

\section{Results}

From the above analysis, we conclude that the government has the power to promote its ideology, and this can be done through textbooks. The English course recognized by Punjabi textbooks is more than just a book to learn more about English. These textbooks often know a person's status and social class. Its focus is to promote English, so that capable students can be recognized in society, and the medium of instruction in public schools is Urdu. From the above analysis, some texts may violate the genre structure, but the existence of certain characteristics classifies them as respected genres for ideological purposes. The language and content used in books tend to promote a specific set of beliefs and ideas. These textbooks implicitly promote ideologies that help build religious, national, and moral identities. Understanding one's tendency towards a certain identity will give us authority and prominence in the world. It is only conducted in public schools, while private schools have other purposes. Religious identity is cultivated through the implementation of Islamic events, Islamic figures, Islamic architects, and their history. Through the incarnation of national hero events, promote national thinking, encourage students to play a role in national construction, promote patriotism, and promote national spirit. Moral identity is promoted through the beautiful story of how a person understands the lives of others.

\section{Conclusion}

The purpose of any institution, government, or organization is to teach English to be able to live in a social world. To know English means the guarantee to have a stable job and a door open to all opportunities, but, it may not the purpose of any government. The Governments have power and access to promote their ideologies and this can be done through textbooks. The English curriculum approved by Punjab textbooks is more than a book that provides an insight into English. These textbooks tend to know a person's status and to which social grading they lie. Their focal point is to promote English, to able students to be recognized socially whilst the medium of the teaching of government schools is Urdu. Students develop literacies in Urdu and English language, Urdu being a national language is only spoken by $7.08 \%$ of the total population. This means that the governmentapproved textbooks are unable to make a student to use their knowledge of the language globally rather they violate the genres and tends to promote the ideological practices of a domineering group. From the above analysis, some texts may violate genre structure, but the presence of some features 
classifies them in respected genres to achieve ideological purposes. The language as well as the content used in the books is inclined to promote a particular set of beliefs and ideas. These textbooks implicitly promote ideologies that help in the religious, national, and moral identity establishment. By knowing one's inclination toward an identity, gives us authority and prominence in the world. It is only done in government schools while private schools have other purposes. Religious identity is fostered by implementing incidents from Islam, Islamic personalities, Islamic architect, and its history. National ideologies are promoted through the incarnation of incidents of national heroes, to encourage the feeling of patriotism and to promote the nation by uplifting students to play their part in making a nation strong. Moral identities are promoted through the stories of how one can take lesson of goodness from others' lives. Though most of the students attend schools and are unable to attend Universities so an immense part of their ideologies is developed through school that they foster up further in a social world. By doing so we are making an orthodox society that limits a person's rationale and confined them in particular scenarios. By imposing religious ideology, the rights of minorities (Hindus, Christians, etc) are suppressed and they are supposed to read Muslim ideology. There is no presence of a single text in the textbooks that promote the religion of the minorities and their culture though they are playing an active role in society. This shows the dominance of one group over the other and the minorities are discouraged and are neglected at a wider level. These can cause restlessness in society and makes people jumbled upon knowing who exactly they are.

\section{Reference}

Apple, M., \& Apple, M. W. (2018). Ideology and curriculum. Routledge.

Apple, Michael W. 1978. Ideology and curriculum. London: Routledge.

Barnard, C. (2004). Language, ideology and Japanese history textbooks. Routledge.

Benwell, B., \& Stokoe, E. (2006). Discourse and identity. Edinburgh University Press.

Bernstein, B. (1998). Pedagogy, symbolic control and identity: Theory, research, critique. BRITISH JOURNAL OF EDUCATIONAL STUDIES, 46, 86-86.

Brânzilă, C. I. (2018). Identity and Education in the Case of Children's Literature. Hermeneia: Journal of Hermeneutics, Art Theory \& Criticism, (21).

Bucholtz, M., \& Hall, K. (2004). Language and identity. A companion to linguistic anthropology, 1, 369-394.

Bucholtz, M., \& Hall, K. (2005). Identity and interaction: A sociocultural linguistic approach. Discourse studies, 7(4-5), 585-614.

Curdt-Christiansen, X. L., \& Weninger, C. (Eds.). (2015). Language, ideology and education: The politics of textbooks in language education. Routledge.

de Fina, A. E., Schiffrin, D. E., \& Bamberg, M. E. (2006). Discourse and identity. Cambridge University Press.

Halliday, M. A. K. (1978). Language as social semiotic: The social interpretation of languge and meaning. Hodder Education.

Halliday, M. A. K., \& Matthiessen, C. M. (2013). Halliday's introduction to functional grammar. Routledge.

Halliday, M.A.K., \& Matthiessen, M.I.M. (2014). Halliday's Introduction to Functional Grammar. (4th edn). Taylor and Francis Group: Routledge.

Hart, D. (2005, January). The development of moral identity. In Nebraska symposium on motivation (Vol. 51, p. 165-175).

Hasan, R. (2009). Semantic variation: Meaning in society and in sociolinguistics (Vol. 2). London: Equinox. 
Hodge, R., \& Kress, G. R. (1993). Language as ideology (Vol. 2). London: Routledge.

Kopytowska, M. (2012). Critical Perspectives on Ideology, Identity, and Interaction. Critical Approaches to Discourse Analysis across Disciplines, 5(2), 1-14.

Mahboob, A. (2015). Identity management, language variation and English language textbooks: Focus on Pakistan. Language and identity across modes of communication, 6, 153.

Mahmoodi-Shahrebabaki, M. (2018). Language and identity: A critique. Journal of Narrative and Language Studies.

Martin, J. R. \& David, R. (2008). Genre relations: Mapping culture. London \& Oakville: Equinox.

Martin, J. R., \& Rose, D. (2008). Getting going with genre. Genre Relations-Mapping Culture. Equinox eBooks Publishing, United Kingdom.

Martin, J.R. (1991) Intrinsic functionality: implications for contextual theory. Social Semiotics 1(1): 99-162.

Martin, J.R. (2000). 'Close Reading: Functional linguistics as a tool for critical discourse analysis', in L. Unsworth (edn). Researching Language in schools and communities: Functional Linguistic Perspective. London: Cassell, pp. 275-302.

Milner, H. R. (2010). Culture, curriculum, and identity in education. In Culture, curriculum, and identity in education (pp. 1-11). Palgrave Macmillan, New York.

Nunan, D., Candlin, C. N., \& Widdowson, H. G. (1988). Syllabus design (Vol. 55). Oxford: Oxford University Press.

Popow, M. (2014). The analysis of discursive constructions of national identity in Polish literature textbooks. IARTEM e-Journal, 6(2).

Rose, D. \& Martin. J.R. (2012). Learning to write, reading to learn: Genre, knowledge and pedagogy in the Sydney School. London: Equinox.

Shah, S. K., Tariq, W., \& Bilal, M. (2013). Ideology in English textbooks: A case study of matric level books in Punjab. Research on Humanities and Social Sciences, 3(11), 113-120.

Swales, J. (1990). Genre analysis: English in academic and research settings. Cambridge University Press.

Verschueren, J. (2012). Ideology in language use: Pragmatic guidelines for empirical research. Cambridge University Press.

Wang, D. (2016). Learning or becoming: Ideology and national identity in textbooks for international learners of Chinese. Cogent Education. 